\title{
Workplace injury and associated factors among construction workers in Gondar town, Northwest Ethiopia
}

\author{
Fentahun Berhanu1, Mulat Gebrehiwot ${ }^{2}$ and Zemichael Gizaw ${ }^{2^{*}}$ (D)
}

\begin{abstract}
Background: The construction industry is one of the most hazardous working areas, where the highest number of labourers engaged. However, the predisposing factors for occupational injury in the construction sites in Ethiopia are not well investigated. This study was, therefore, conducted to assess the magnitude of occupational injury and associated factors among construction workers in Gondar town, northwest Ethiopia.
\end{abstract}

Methods: This cross-sectional study was conducted on 566 construction workers. Systematic random sampling technique was used to select study subjects. Data were collected using structured questionnaire and observation checklist. Multivariable binary logistic regression analysis was used to identify variables significantly associated with occupational injury on the basis of adjusted odds ratio (AOR) with 95\% confidence interval (Cl) and $p<0.05$.

Results: The overall prevalence of work-related injury in 3 months prior to the survey was found to be 39\% (95\% $\mathrm{Cl}=35.0-43.1 \%)$. The occurrence of occupational injury was associated with single workers $[\mathrm{AOR}=0.50,95 \% \mathrm{Cl}=$ $0.25,0.97]$, longer service year $[A O R=2.79,95 \% \mathrm{Cl}=1.72-4.53]$, poor attention to work $[\mathrm{AOR}=2.65,95 \% \mathrm{Cl}=1.33$, 5.29], working with vibrating hand tools $[\mathrm{AOR}=3.23,95 \% \mathrm{Cl}=1.19,8.76]$, no aware about occupational hazards $[\mathrm{AOR}=4.66,95 \% \mathrm{Cl}=1.99,10.87]$, and alcohol consumption $[\mathrm{AOR}=3.16,95 \% \mathrm{Cl}=2.09,4.79]$.

Conclusion: High prevalence of occupational injury was reported in the study area. Cut and fall were the leading causes. Marital status, service year, attention to work, use of vibrating hand tools, awareness about occupational hazards, and drinking alcohol were identified as factors associated with occupational injury. Therefore, health and safety trainings have to be taken place to aware workers about occupational injury and safety issues. Regular workplace supervision and provision of appropriate personal protective equipment (PPE) are also needed to prevent occupational injury. The findings of this study are useful to design and implement injury prevention strategies in the country. The study also contributes to the current literature as health and safety information is limited, especially in developing countries.

Keywords: Occupational injury, Construction industry, Northwest Ethiopia

\section{Background}

The construction industry has been considered an accident-prone industry. That is because construction sites are often filled with potential hazards that can lead to serious injury or death $[1,2]$. Construction workers face a risk of fatal and non-fatal injury higher than any other groups of workers [3]. Although countries differ

\footnotetext{
* Correspondence: Zemichael12@gmail.com

${ }^{2}$ Department of Environmental and Occupational Health and Safety, Institute of Public Health, College of Medicine and Health Sciences, University of Gondar, Gondar, Ethiopia

Full list of author information is available at the end of the article
}

substantially in their structural industrial distribution or level of occupational health and safety, injuries in the construction industries are the major health and safety concerns in many countries [4]. Moreover, the rate of death of workers is higher in the construction industry than in any other industry [1].

Within the construction industry, the risk of fatality is 5 times higher than in manufacturing, whilst the risk of a major injury is 2.5 times higher [5]. The problem of death and injury as a result of the workplace accident has now been recognized as a global phenomenon. The

(c) The Author(s). 2019 Open Access This article is distributed under the terms of the Creative Commons Attribution 4.0 International License (http://creativecommons.org/licenses/by/4.0/), which permits unrestricted use, distribution, and reproduction in any medium, provided you give appropriate credit to the original author(s) and the source, provide a link to the Creative Commons license, and indicate if changes were made. The Creative Commons Public Domain Dedication waiver (http://creativecommons.org/publicdomain/zero/1.0/) applies to the data made available in this article, unless otherwise stated. 
construction industry accounts for 55,000 fatal injuries each year [1]. Besides, construction injury causes huge economic losses. Globally, the direct and indirect costs of fatal and nonfatal construction injury have been estimated over 10 billion USD per year [6].

Accident causalities in the construction industry is complex and multifaceted and accident prevention begins with having a clear understanding of those factors [7]. Personal and work characteristics combined with the working environment and organizational factors are believed toinfluence the creation of a hazardous environment that could be triggered by differentmechanisms that cause an accident [8-10]. Most of the accidents in the construction industry occurred because of insufficient safety measures [11]. Human errors are mainly responsible forconstruction accidents [12-14]. Site conditions or work environments play an important role in construction accidents [10]. Moreover, the temporary and transitory nature of construction sites are claimed to contribute to accidents [15]. While environmental factors such as climate, temperature, and geographical conditions could be considered as typical characteristics for construction sites [16]. Organizational factors may include characteristics referring to construction organisations and project-based procurement of works [17]. Size of company [18-20], age [21-24], gender [18-20, 25], education [19] and type of work [26-28] are also associated with occupational injury.

In the developed countries, several attempts have been made to investigate factors influencing safety performance on construction sites. However, the predisposing factors for occupational injury in the construction sites in Ethiopia are not well investigated. This study was, therefore, conducted to assess the magnitude of occupational injury and associated factors among construction workers in Gondar town, northwest Ethiopia.

\section{Methods}

\section{Design and settings of the study}

An institutional-based cross-sectional study design was conducted among construction workers in Gondar town. More than 20 construction sites were found in Gondar town as of April 2015 and the major sites are owned by eight different companies. Around 2586 workers were engaged in different working units in all sites. Workers who directly engaged in different working units were considered as study subjects and workers who were not engaged in construction works like administrative workers were excluded from the study.

\section{Sample size determination}

The sample size was determined using single population proportion formula with the following assumptions: prevalence of occupational injury $(\mathrm{p})=38.7 \%$ [29], margin of error $(w)=4,95 \%$ confidence interval (standard normal probability), and level of significance $(\alpha)=4$.

Therefore, the sample size (n) was computed as $n$ $=\frac{(z \alpha / 2)^{2} p(1-p)}{w^{2}}=\frac{(1.96)^{2} 0.387(1-0.387)}{0.04^{2}}=569$. The final sample was found to be 596 considering 5\% non-response rate.

\section{Sampling technique and sampling procedure}

More than 20 construction sites with more than 2586 workers are found in Gondar town as of April 2015. Eight construction sites were selected using simple random sampling technique. All workers who actively engaged in different sections were included and persons who had no exposure to occupational hazards like office workers were excluded from the study. Hence, the number of workers at each site varied; the sample size was proportionally allocated (Table 1 ). Finally, the study subjects from each site were selected by simple random sampling technique (using random number generator) using workers in the registration book as a sampling frame.

\section{Description of study variables Dependet variable}

Occupational injury, the primary outcome variable of this study, is defined as any physical damage of the human body or tissue like laceration, cut, puncture, fracture, dislocation, amputation, electrocution, ear injury, and eye injury results from harmful contact between people and objects, substances, or other things in their surroundings.

\section{Independet variables}

Utilization of PPEs Is defined as use of suitable protective equipment like hand glove, toetector/feet wear, respirator, face mask, reinforced cloth, goggle and helmet on duty.

Table 1 Distribution of study participants in the eight construction sites in Gondar town, northwest Ethiopia, April 2015

\begin{tabular}{ll}
\hline Construction sites & Number of participants \\
\hline Amhara Wuhawoch Drigit & 303 \\
Nigidu Kibrit & 105 \\
Unity Engineering & 58 \\
3 M Construction & 53 \\
Medrock Construction & 27 \\
Afrotsione Construction & 22 \\
Alemayew Ketema Construction & 15 \\
Aielmi Construction & 13 \\
\hline
\end{tabular}


Manual handling Is defined as any load by physical effort incorporates lifting, pushing, pulling, putting down, caring and moving from the ground level and higher level.

Health and safety training Is any formal or informal health and safety education provided for workers to create basic understanding of occupational health, workplace hazards, injury prevention and safety.

Attention to work Is a physical and mental due attention or focus given for the work only.

Alcohol use Male and female participants who drink more than six and five glasses or bottles or cans of any alcoholic beverage, such as beer, wine and Tela (local beverage) respectively on a regular work or weekend days, including the off-work hours were considered as drunker.

Hazard awareness Is defined as an existed knowledge or understanding of occupational hazards.

Moreover, health and safety supervision, working hours per week, working section, and socio-demographic characteristics were other predictor variables considered in this study.

\section{Data collection tools and data collection procedures}

Data were collected using a structured questionnaire and observational checklists. The data collection tools were adopted from other similar published studies [2931] with simple modification to address contextual issues related to study setting and participants. The questionnaire consisted of socio-demographic information, work-related injury characteristics, work environment and ergonomic related information, and workers behavior-related information. The tools were pretested on workers who were not actually part of the study having similar characteristics with the study subjects in different town and necessary correction was done. Training was given for data collectors and supervisors on data collection procedures and data collection tools. The overall physical condition of the workers and the working condition were observed using checklists [32-35]. Working conditions and safety practices were the items included in the checklists. We immediately checked and corrected completeness of data before the collectors move to the next interview. Supervisors checked the completeness of all the filled questionnaires daily and $5 \%$ of the collected questionnaires were repeated. Furthermore, double data entry and software assisted data cleaning were employed.

\section{Data processing and analysis}

Data were entered using EPI-INFO version 3.5.3 and exported to statistical package for social sciences (SPSS) version 20.0 for further analysis. Univariable binary logistic regression analysis was used to choose variables for the multivariable binary logistic regression analysis on the basis of $p$-value less than 0.2 . In the multivariable binary logistic regression analysis, statistically significant variables were identified on the basis of AOR with $95 \% \mathrm{CI}$ and $p<0.05$. Model goodness-of-fit was checked by Hosmer-Lemeshow test. Multicollinearity was also checked.

\section{Results}

\section{Socio-demographic characteristics}

In this study, 566 construction workers participated. This gives 95\% response rate. Of these, 295 (52.1\%) were male. The mean age of the participants was 25.78 years with \pm 6.58 standard deviation. Three hundred fifty (61.8\%) of the workers attended primary education. Three hundred ninetynine $(70.5 \%)$ of the study subjects had five and below years of work experience in the construction industry. About twothird, $358(63.3 \%)$ of the construction workers were daily labourers (Table 2).

\section{Working condition and workers behaviour}

Fifty-four (9.5\%) of the respondents worked for more than $48 \mathrm{~h}$ per week. Four hundred fifty-seven $(80.7 \%)$ of the respondents had not been regularly supervised at work and $483(85.3 \%)$ of the study subjects had not ever taken safety and health training. Four hundred sixtythree $(81.8 \%)$ of the study subjects responded that their job involved manual handling and 530 (93.6\%) of the workers worked with vibrating hand tools (Table 3). Four hundred fifty (79.5\%) of the respondents were not using PPEs while working. The most frequently reported reason for not using PPEs was shortage of devices, which accounts for $98.2 \%$. The remaining $116(20.5 \%)$ of workers used PPEs. Helmet (33.6\%), glove (27.6\%), overall (18.1\%), boots/shoes (8.6\%), earplug (6.9\%), respirator (2.6\%), and goggle (2.6\%) were commonly reported PPEs. The result of this study also showed that 17 (3\%), 318 $(56.2 \%)$ and $16(2.8 \%)$ of the study subjects were smoker, drunker, and chat chewer respectively.

\section{Magnitude of occupational injury}

Out of 566 construction workers who directly engaged at different working units, 221 were injured in the last 3 months. Therefore, the overall prevalence of work-related injury was found to be $39 \%$ (95\% CI $=35.0-43.1 \%)$. Of the injured workers, 56 (25.34\%) experienced work-related injury more than once (Table 4). Abrasion or laceration was the leading type of injury, which accounts for 108 (48.75\%). The commonest causes of injury were found to be cut by sharp objects, $62(28.05 \%)$ and fall to ground level, 52 (23.54\%) 
Table 2 Socio-demographic characteristics of construction workers ( $n=566)$ in Gondar town, April 2015

\begin{tabular}{|c|c|c|}
\hline Socio-demographic variables & Frequency & Percent \\
\hline \multicolumn{3}{|l|}{ Sex } \\
\hline Female & 271 & 47.9 \\
\hline Male & 295 & 52.1 \\
\hline \multicolumn{3}{|l|}{ Age } \\
\hline $14-29$ & 550 & 97.2 \\
\hline$>30$ & 16 & 2.8 \\
\hline \multicolumn{3}{|l|}{ Educational status } \\
\hline Blow grade 8 & 350 & 61.8 \\
\hline 9-12 grade & 160 & 28.3 \\
\hline Diploma and above & 56 & 9.9 \\
\hline \multicolumn{3}{|l|}{ Marital status } \\
\hline Married & 196 & 34.6 \\
\hline Separated & 301 & 53.2 \\
\hline Single & 69 & 12.2 \\
\hline \multicolumn{3}{|l|}{ Monthly income } \\
\hline$\leq 1000$ & 367 & 64.8 \\
\hline$>1000$ & 199 & 35.2 \\
\hline \multicolumn{3}{|l|}{ Working experience } \\
\hline$\leq 5$ years & 399 & 70.5 \\
\hline$>5$ years & 167 & 29.5 \\
\hline \multicolumn{3}{|l|}{ Occupational title } \\
\hline Daily labors & 358 & 63.3 \\
\hline Carpenter & 74 & 13.1 \\
\hline Builders & 47 & 8.3 \\
\hline Plaster & 36 & 6.4 \\
\hline Driver/Operator1 & 32 & 5.6 \\
\hline Welders/electrician & 19 & 3.4 \\
\hline \multicolumn{3}{|c|}{ Daily labors which involving the work $(n=358)$} \\
\hline Lifting and carrying stone and cement & 164 & 45.8 \\
\hline Helping the painter & 75 & 20.9 \\
\hline Helping the builders & 45 & 12.6 \\
\hline Mason & 40 & 11.2 \\
\hline Helping the carpenter & 34 & 9.5 \\
\hline
\end{tabular}

(Table 5). The two most reported reasons for injury were the nature of the work (52.03\%) and not using PPEs (16.74\%) (Fig. 1). Eighty-four (38\%) of injury cases were managed in the construction sites using first aid services whereas, 111 (50.2\%) and 25 (13.3\%) of the injured workers respectively reported as they visited health institution and as they used traditional medicine to manage the injury.

\section{Factors associated with occupational injury}

Sex, marital status, service year, safety training, attention to work, work with vibrating hand tools, hazard awareness, and
Table 3 Working environment and ergonomic related factors among construction workers $(n=566)$ in Gondar town, April 2015

\begin{tabular}{|c|c|c|}
\hline Work environment and ergonomic related factors & Frequency & percent \\
\hline \multicolumn{3}{|l|}{ Hours per week } \\
\hline$\leq 48 \mathrm{~h}$ & 512 & 90.5 \\
\hline$>48 \mathrm{~h}$ & 54 & 9.5 \\
\hline \multicolumn{3}{|l|}{ OSHS safety supervision } \\
\hline Yes & 109 & 19.3 \\
\hline No & 457 & 80.7 \\
\hline \multicolumn{3}{|l|}{ Safety training } \\
\hline Yes & 83 & 14.7 \\
\hline No & 483 & 85.3 \\
\hline \multicolumn{3}{|l|}{ Manual handling } \\
\hline Yes & 463 & 81.8 \\
\hline No & 103 & 18.2 \\
\hline \multicolumn{3}{|c|}{ Weight of objects manually handled $(n=463)$} \\
\hline Light (not greater than 5 Kg) & 132 & 28.5 \\
\hline Medium $(6-10 \mathrm{Kg})$ & 58 & 12.5 \\
\hline Heavy $(11-20 \mathrm{Kg})$ & 54 & 11.7 \\
\hline Very heavy (> 20 k.g) & 219 & 47.30 \\
\hline \multicolumn{3}{|l|}{ Time spend on manual handling /day $(n=463)$} \\
\hline$<2 \mathrm{~h}$ & 21 & 4.5 \\
\hline $2-4 h$ & 76 & 16.5 \\
\hline$>4 \mathrm{~h}$ & 366 & 79 \\
\hline \multicolumn{3}{|l|}{ Concentration at the work } \\
\hline Yes & 492 & 86.9 \\
\hline No & 74 & 13.1 \\
\hline \multicolumn{3}{|l|}{ Working with vibrating hand tools } \\
\hline Yes & 530 & 93.6 \\
\hline No & 36 & 6.4 \\
\hline \multicolumn{3}{|l|}{ Hazard awareness } \\
\hline Yes & 497 & 87.2 \\
\hline No & 69 & 12.2 \\
\hline
\end{tabular}

alcohol consumption were selected for the multivariable analysis. As clearly indicated in Table 6, marital status, service year, attention to work, work with vibrating hand tools, awareness about occupational hazards and alcohol consumption were statistically associated with the occurrence of occupational injury in the final model. The occurrence of occupational injury among single construction workers was $50 \%$ to be lower compared with married workers [AOR = $0.50,95 \% \mathrm{CI}=0.25,0.97]$. The likelihood of injury occurrence among workers who worked for more than 5 years was 2.79 times to be higher compared with workers who worked for five and below years $[\mathrm{AOR}=2.79,95 \% \mathrm{CI}=1.72$, 4.53]. Those construction workers who had no attention to 
Table 4 Work-related injury among construction workers in Gondar town ( $n=566)$, Ethiopia, April 2015

\begin{tabular}{|c|c|c|}
\hline Occurrence of injury & Frequency & percent \\
\hline \multicolumn{3}{|c|}{ Injury in the last 3 months } \\
\hline Yes & 221 & 39.0 \\
\hline No & 345 & 61.0 \\
\hline \multicolumn{3}{|l|}{ Number of occurrence } \\
\hline Once & 165 & 76.7 \\
\hline More than once & 56 & 25.3 \\
\hline \multicolumn{3}{|c|}{ Injury in the last 2 weeks } \\
\hline Yes & 77 & 13.6 \\
\hline No & 489 & 86.4 \\
\hline \multicolumn{3}{|l|}{ Number of occurrence } \\
\hline Once & 68 & 88.3 \\
\hline More than once & 9 & 11.7 \\
\hline
\end{tabular}

work were 2.65 times to be injured compared with their counterparts $[\mathrm{AOR}=2.65,95 \% \mathrm{CI}=1.33,5.29]$. Workers who worked with vibrating hand tools were 3.23 times to be injured $[\mathrm{AOR}=3.23,95 \% \mathrm{CI}=1.19,8.76]$. Workers who had no awareness about occupational hazards were 4.66 times more likely to be injured $[\mathrm{AOR}=4.66,95 \% \mathrm{CI}=1.99,10.87$ ]. The occurrence of injury was 3.16 times to be higher among construction workers who are drinkers $[\mathrm{AOR}=3.16,95 \%$ $\mathrm{CI}=2.09,4.79]$.

\section{Discussion}

The overall three-month prevalence of occupational injury among construction workers in Gondar town was $39 \%$ (95\% CI $=35.0-43.1 \%$ ). The prevalence reported in this study is the same with findings of studies in Gondar city, 38.7\% [30]; Maraki campus, University of Gondar, 38.7\% [29]; Southeastern Ethiopia, 41.4\% [36]; southwestern Ethiopia, 39.2\% [37]; Addis Ababa, 38.3\% [35]; and Nigeria, 39.25\% [38]. The result of this study is lower than the results of other studies in Addis Ababa, 84.7\% [31] and 67.7\% [39], Iran, 79.8\% [40]; Tamil Nadu, 44.3\% [41]; and Egypt, 46.2\% [42]. The result of this study is also higher than the report of other studies in Gondar, 15\% [43]; Uganda, 32.4\% [44]; and China $34.82 \%$ [45]. This difference might be due to differences in study settings, working conditions, level of accident prevention strategies, and socio-cultural and regulatory factors. In this study, the prevalence of occupational injury is high may be due to no regular workplace supervision, poor PPEs utilization, use of manually handled vibrating construction materials, and long working hours per week.

In this study, a significant proportion of young workers engaged in the construction industry. Young workers are at higher risk of occupational injury than older age groups. Young workers face higher
Table 5 Type and causes of injury and body parts affected among workers $(n=221)$ in construction enterprise, Gondar town, Ethiopia, April 2015

\begin{tabular}{|c|c|c|}
\hline Variables & Frequency & percent $(\%$ \\
\hline \multicolumn{3}{|l|}{ Types of injury } \\
\hline Abrasion /laceration & 108 & 48.9 \\
\hline Puncture & 36 & 16.3 \\
\hline Dislocation & 20 & 9.0 \\
\hline Eye injury & 17 & 7.7 \\
\hline Cut & 14 & 6.3 \\
\hline Fracture & 13 & 5.9 \\
\hline Back pain & 8 & 3.6 \\
\hline Electrocution & 2 & 0.9 \\
\hline Amputation & 1 & 0.5 \\
\hline \multicolumn{3}{|l|}{ Causes of injury } \\
\hline Cut by sharp objects & 62 & 28.1 \\
\hline Falls of the ground level & 52 & 23.5 \\
\hline Falling from the height & 43 & 19.5 \\
\hline Hit by falling objective & 17 & 7.6 \\
\hline Being struck machine & 14 & 6.3 \\
\hline Over exertion during lifting & 18 & 8.1 \\
\hline struck by moving machine & 9 & 4.1 \\
\hline Contact electric line & 5 & 2.3 \\
\hline Others & 7 & 3.2 \\
\hline \multicolumn{3}{|l|}{ Parts of the body affected } \\
\hline Hand & 88 & 39.8 \\
\hline Toes & 45 & 20.4 \\
\hline Eye & 29 & 13.0 \\
\hline Leg figures & 13 & 5.8 \\
\hline Head & 9 & 4.0 \\
\hline Back & 9 & 4.0 \\
\hline Upper leg & 6 & 2.7 \\
\hline Lower leg & 6 & 2.7 \\
\hline Chest & 4 & 1.8 \\
\hline Upper arm & 4 & 1.8 \\
\hline Knee & 3 & 1.3 \\
\hline Lower arm & 1 & 0.5 \\
\hline Ear & 1 & 0.5 \\
\hline Others & 3 & 0.1 \\
\hline
\end{tabular}

occupational injury risks related to their higher vulnerability. Some known contributors to youth workplace injury include potential lack of specific job training. Many youth are not aware of their legal rights and are thus illequipped to identify potential hazards and request training to appropriately manage these hazards. Youth may also feel intimidated in the workplace. They may feel powerless to change their working conditions, or too shy 


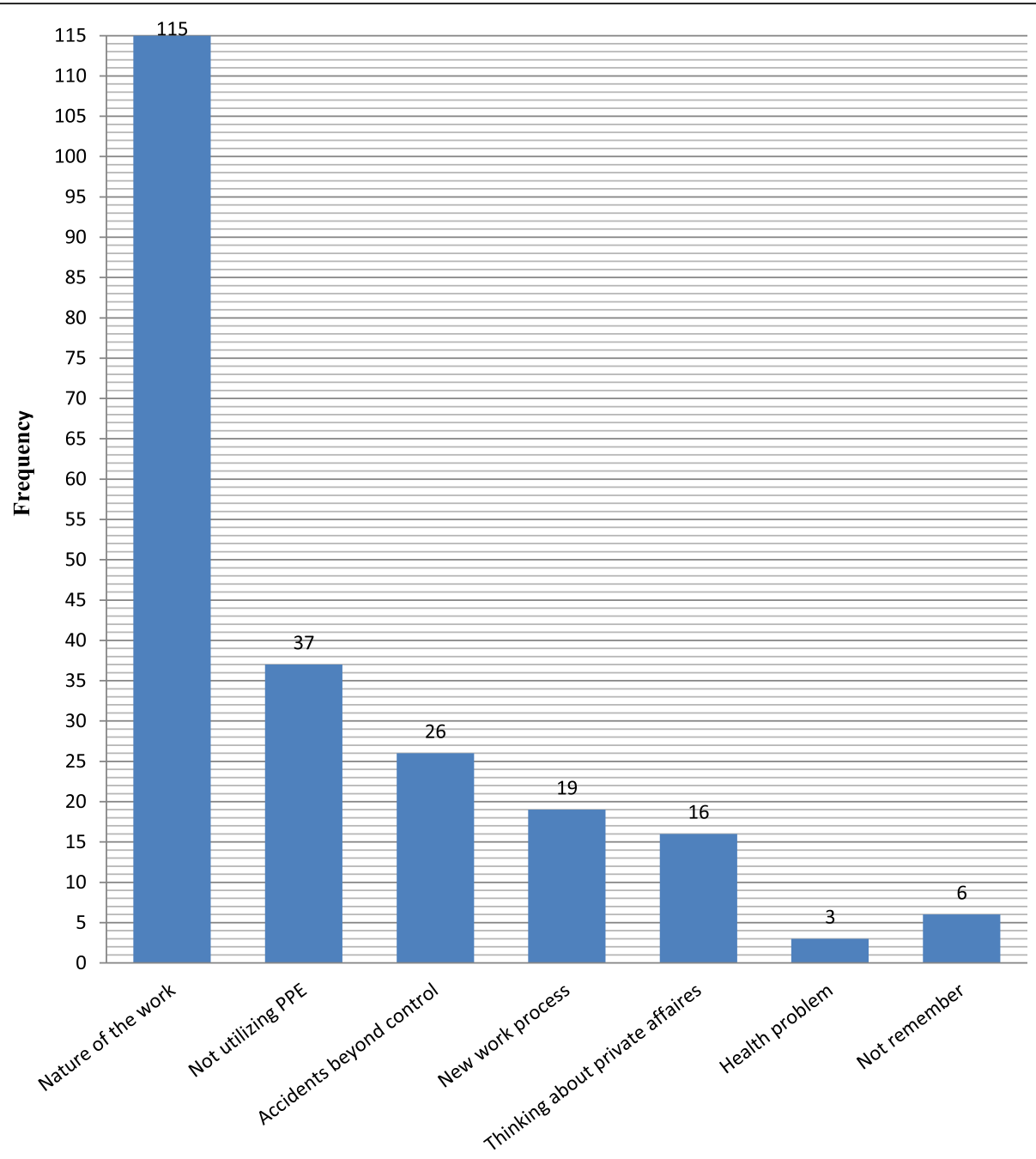

Reasons for occurence

Fig. 1 Reported reasons for occurrence of work-related injury by construction workers in Gondar town, April 2015

to voice their concerns if they are new in their working environment [46-49].

In this study, the occurrence of occupational injury among single construction worker was $50 \%$ lower compared with married workers. The finding of this study is supported by another similar study [50]. This may be due to married workers may engage in other works without taking adequate rest. Stress and fatigue can be higher among married workers than single ones because of higher responsibilities in life. It may be led to more unsafe acts resulting in accident [50-52].

This study depicted that workers who reported longer working years had greater chance to occupational injury. This might be explained that accidents usually occur to workers who could still have had a long working career. Those engaged in routine activities for a long period with poor working environment may sustain job dissatisfaction; the work is insecure so that workers stayed for a long period in this insecure job had an increased vulnerability of different injury [35, 53-55].

The current study identified that due attention to work was associated with the occurrence of occupational injury. The odds of injury among construction workers who had no attention to work was higher than workers who had. This might be due to the fact that those workers who had no attention to work did not comply with standard work procedures, safety precautions including proper use of PPEs. In addition, workers who had no attention to work would also create hazards to their co-workers. There is some evidence to suggest that there is a link between accidents and distractibility, poor attention and mental error [56-58].

This study revealed that workers who used vibrating hand tools were more likely to be injured compared with their counterparts. This may be due to the type of hand tools in which construction workers used to operate 
Table 6 Factors associated with occupational injury $(n=566)$ in Gondar town construction enterprise, April 2015

\begin{tabular}{|c|c|c|c|c|}
\hline \multirow{2}{*}{$\begin{array}{l}\text { Predictor } \\
\text { variables }\end{array}$} & \multicolumn{2}{|c|}{ Occupational injury } & \multirow[t]{2}{*}{ COR (95\% Cl) } & \multirow[t]{2}{*}{$\mathrm{AOR}(95 \% \mathrm{Cl})$} \\
\hline & Yes & No & & \\
\hline \multicolumn{5}{|l|}{ Sex } \\
\hline Female & 126 & 145 & 1.00 & 1.00 \\
\hline Male & 95 & 200 & $1.83(1.31,2.60)$ & $1.43(0.95,2.17)$ \\
\hline \multicolumn{5}{|l|}{ Marital status } \\
\hline Married & 85 & 111 & 1.00 & 1.00 \\
\hline Separated & 97 & 204 & $1.61(1.11,2.33)$ & $1.32(0.84,2.08)$ \\
\hline Single & 39 & 30 & $0.60(0.34,1.05)$ & $0.50(0.25,0.97)^{*}$ \\
\hline \multicolumn{5}{|l|}{ Service year } \\
\hline$<5$ years & 188 & 211 & 1.00 & 1.00 \\
\hline$>5$ years & 33 & 134 & $3.61(3.35,5.54)$ & $2.79(1.72,4.53) * * *$ \\
\hline \multicolumn{5}{|c|}{ Safety training } \\
\hline Yes & 42 & 41 & 1.00 & 1.00 \\
\hline No & 179 & 304 & $1.74(1.09,2.78)$ & $1.46(0.84,2.53)$ \\
\hline \multicolumn{5}{|c|}{ Concentration at work } \\
\hline Yes & 208 & 284 & 1.00 & 1.00 \\
\hline No & 13 & 61 & $3.43(1.84,6.42)$ & $2.65(1.33,5.29)^{* *}$ \\
\hline \multicolumn{5}{|c|}{ Work with vibrating tools } \\
\hline Yes & 215 & 315 & 1.00 & 1.00 \\
\hline No & 6 & 30 & $3.41(1.39,8.34)$ & $3.23(1.19,8.76)^{*}$ \\
\hline \multicolumn{5}{|c|}{ Hazard awareness } \\
\hline Yes & 214 & 283 & 1.00 & 1.00 \\
\hline No & 7 & 62 & $6.69(3.00,14.92)$ & $4.66(1.99,10.87)^{* * *}$ \\
\hline \multicolumn{5}{|c|}{ Alcohol consumption } \\
\hline Yes & 160 & 158 & 1.00 & 1.00 \\
\hline No & 61 & 187 & $3.10(2.15,4.46)$ & $3.16(2.09,4.79)^{* * *}$ \\
\hline
\end{tabular}

Statistically significant variables at $p<\left.0.05\right|^{* *}$ Statistically significant variables at $p<0.01 \mid{ }^{* *}$ Statistically significant variables at $p<0.001 \mid$ The result of Hosmer and Lemshow test was $>0.670 \mid \mathrm{VIF}=4.5$

their work is associated with their physical health. Physical work demands like vibration and heavy lifting aggravating the occurrence of injury. Vibrating tools can cause loss of muscle strength and reduced grip force due to incomplete muscle contraction [59].

This study found that occupational injury was significantly associated with awareness about occupational hazards. The odds of occupational injury among construction workers who had no awareness about occupational hazards was more likely to be higher. The association of awareness and injury can be justified that workers who were not aware about workplace hazards, prevention of injury and other safety measures may do work with wrong procedures and may not also comply with workplace safety strategies [39, 60-62].

This study indicated that the occurrence of occupational injury was associated with alcohol consumption. Construction workers who took alcohol were more likely to be injured compared with their counterparts. This finding is consistent with the findings of other studies $[55,63,64]$. This may be due to the fact that alcohol can impair judgmental and psychomotor skills. Alcohol took before work begins can cause effects such as fatigue and hangovers. Alcoholic workers may be more likely to be engaged in other behaviors that increase the risk of injury [65-67].

\section{Limitation of the study}

Workers who were absent from work due to illness were not included in this study. Therefore, the results of the study might be affected by healthy workers effect. Authors tried to check whether the absenteeism was due to occupational injury or not to minimize healthy workers effect.

\section{Conclusion}

High prevalence of occupational injury was reported in the study area. Cut and fall were the leading causes of 
injury. Marital status, service year, attention to work, use of vibrating tools, awareness about occupational hazards, and drinking alcohol were identified as factors associated with occupational injury. Therefore, health and safety trainings have to be taken place to aware workers about occupational injury and safety issues. Regular workplace supervision and provision of PPEs are also needed to prevent occupational injury. The findings of this study are useful to design and implement injury prevention strategies in the country. The study also contributes to the current literature as health and safety information is limited, especially in developing countries.

\section{Abbreviations}

AOR: Adjusted Odds Ratio; Cl: Confidence Interval; COR: Crude Odd Ratio; PPEs: Personal Protective Equipment; SPSS: Statistical Package for Social Science; VIF: Variance inflation factor

\section{Acknowledgements}

We extended our grateful thanks to Gondar administrative town, Gondar town Labor and Social Affairs office, construction enterprises, construction workers, and data collectors for their fieldwork facilitation, permission and participation.

\section{Authors' contribution}

All the authors actively participated during the conception of the research issue and development of the research proposal. FB supervised the data collection process, entered data to Epi- Info, recoded and processed the entered data. MG and ZG analyzed the data, interpreted the results and prepared the manuscript. All the authors read and approved the final manuscript.

\section{Funding}

This study had no special fund. However, University of Gondar had covered questionnaire duplication and data collection fee.

\section{Availability of data and materials}

Data will be made available upon requesting the primary author.

\section{Ethics approval and consent to participate}

Ethical clearance was obtained from institutional review board of the University of Gondar. There were no risks due to participation in this research. The collected data were used only for this research purpose. Verbal informed consent was obtained from the participants. Informed verbal consent was also obtained from the parents for participants aged below 18 years. The verbal consent was approved by the institutional review board of the University of Gondar. Confidentiality was granted for the information collected from each worker and privacy during the interview was ensured. The interviews were administered without the presence of managers or supervisors to ensure privacy.

\section{Consent for publication}

This manuscript does not contain any individual person's data.

\section{Competing interests}

The authors declare that they have no competing interests.

\section{Author details}

${ }^{1}$ Lideta sub-city administration, Gondar, Ethiopia. ${ }^{2}$ Department of Environmental and Occupational Health and Safety, Institute of Public Health, College of Medicine and Health Sciences, University of Gondar, Gondar, Ethiopia.
Received: 8 February 2019 Accepted: 29 October 2019

Published online: 09 November 2019

\section{References}

1. ElSafty A, ElSafty A, Malek M. Construction safety and occupational health education in Egypt, the EU, and US firms. Open J Civil Eng. 2012;2(03):174.

2. Sherratt F, Farrell P, Noble R. UK construction site safety: discourses of enforcement and engagement. Constr Manag Econ. 2013;31(6):623-35.

3. Brenner $H$, Ahern W. Sickness absence and early retirement on health grounds in the construction industry in Ireland. Occup Environ Med. 2000; 57(9):615-20

4. Hämäläinen P, Takala J, Saarela KL. Global estimates of occupational accidents. Saf Sci. 2006;44(2):137-56.

5. Khosravi Y, Asilian-Mahabadi H, Hajizadeh E, Hassanzadeh-Rangi N, Bastani $\mathrm{H}$, Behzadan $\mathrm{AH}$. Factors influencing unsafe behaviors and accidents on construction sites: a review. Int J Occup Saf Ergon. 2014;20(1):111-25.

6. Gittleman JL, Gardner PC, Haile E, Sampson JM, Cigularov KP, Ermann ED, et al. [case study] CityCenter and cosmopolitan construction projects, Las Vegas, Nevada: lessons learned from the use of multiple sources and mixed methods in a safety needs assessment. J Saf Res. 2010;41(3):263-81.

7. Gambatese JA, Behm M, Rajendran S. Design's role in construction accident causality and prevention: perspectives from an expert panel. Saf Sci. 2008; 46(4):675-91.

8. Dumrak J, Mostafa S, Kamardeen I, Rameezdeen R. Factors associated with the severity of construction accidents: the case of South Australia. Construc Econ Build. 2013;13(4):32-49.

9. Cheng C-W, Leu S-S, Cheng Y-M, Wu T-C, Lin C-C. Applying data mining techniques to explore factors contributing to occupational injury in Taiwan's construction industry. Accid Anal Prev. 2012;48:214-22.

10. Chi S, Han S, Kim DY. Relationship between unsafe working conditions and workers' behavior and impact of working conditions on injury severity in US construction industry. J Constr Eng Manag. 2012;139(7):826-38.

11. Gohardani AS, Björk F. A conceptual disaster risk reduction framework for health and safety hazards in the construction industry. Manag Market J. 2013;11(1):173-192.

12. Choudhry RM, Fang D. Why operatives engage in unsafe work behavior: investigating factors on construction sites. Saf Sci. 2008;46(4):566-84.

13. Hinze J, Huang $X$, Terry $L$. The nature of struck-by accidents. J Constr Eng Manag. 2005;131(2):262-8.

14. Al-Humaidi $\mathrm{H}$, Tan FH. Construction safety in Kuwait. J Perform Constr Facil. 2010:24(1):70-7.

15. Hallowell MR, Gambatese JA. Construction safety risk mitigation. J Constr Eng Manag. 2009;135(12):1316-23.

16. Liao C-W, Perng Y-H. Data mining for occupational injury in the Taiwan construction industry. Saf Sci. 2008;46(7):1091-102.

17. Rozenfeld O, Sacks R, Rosenfeld Y, Baum H. Construction job safety analysis. Saf Sci. 2010;48(4):491-8.

18. Ling FYY, Liu M, Woo YC. Construction fatalities in Singapore. Int J Proj Manag. 2009;27(7):717-26.

19. López MAC, Fontaneda I, Alcántara OJG, Ritzel DO. The special severity of occupational accidents in the afternoon:"the lunch effect". Accid Anal Prev. 2011:43(3):1104-16.

20. López MAC, Ritzel DO, Fontaneda I, Alcantara OJG. Construction industry accidents in Spain. J Saf Res. 2008;39(5):497-507.

21. Arquillos AL, Romero JCR, Gibb A. Analysis of construction accidents in Spain, 2003-2008. J Saf Res. 2012;43(5-6):381-8.

22. Chi C-F, Chang T-C, Ting H-I. Accident patterns and prevention measures for fatal occupational falls in the construction industry. Appl Ergon. 2005;36(4): 391-400.

23. Frickmann F, Wurm B, Jeger $V$, Lehmann B, Zimmermann $H$, Exadaktylos AK. 782 consecutive construction work accidents: who is at risk? A 10-year analysis from a Swiss university hospital trauma unit. Swiss Med Wkly. 2012; 142:w13674.

24. Im H-J, Kwon Y-J, Kim S-G, Kim Y-K, Ju Y-S, Lee H-P. The characteristics of fatal occupational injury in Korea's construction industry, 1997-2004. Saf Sci. 2009;47(8):1159-62

25. Lipscomb HJ, Schoenfisch AL, Shishlov KS. Non-fatal contact injury among workers in the construction industry treated in US emergency departments, 1998-2005. J Saf Res. 2010;41(3):191-5.

26. Ale BJ, Bellamy LJ, Baksteen H, Damen M, Goossens LH, Hale AR, et al. Accidents in the construction industry in the Netherlands: an analysis of 
accident reports using Storybuilder. Reliab Eng Syst Safety. 2008;93(10): 1523-33.

27. Gürcanli GE, Müngen U. An occupational safety risk analysis method at construction sites using fuzzy sets. Int J Ind Ergon. 2009;39(2):371-87.

28. Larsson TJ, Field B. The distribution of occupational injury risks in the Victorian construction industry. Saf Sci. 2002;40(5):439-56.

29. Sharma HR, Appadurai S, Wubshet M, Tadess T. Occupational exposures and related health effects among construction workers. Ethiop J Health Biomed Sci. 2008;1(1):41-6.

30. Adane MM, Gelaye KA, Beyera GK, Sharma HR, Yalew WW. Occupational injury among building construction workers in Gondar City, Ethiopia. Occup Med Health Aff. 2013;1(125). https://doi.org/10.4172/2329-6879.1000125.

31. Mersha H, Mereta ST, Dube L. Prevalence of occupational injury and associated factors among construction workers in Addis Ababa, Ethiopia. J Pub Health Epidemiol. 2017;9(1):1-8.

32. Ringen K, Seegal J, England A. Safety and health in the construction industry. Annu Rev Public Health. 1995;16(1):165-88.

33. Ringen K, Stafford EJ. Intervention research in occupational safety and health: examples from construction. Am J Ind Med. 1996;29(4):314-20.

34. Arcury TA, Mills T, Marín AJ, Summers P, Quandt SA, Rushing J, et al. Work safety climate and safety practices among immigrant Latino residential construction workers. Am J Ind Med. 2012;55(8):736-45.

35. Tadesse S, Israel D. Occupational injury among building construction workers in Addis Ababa, Ethiopia. J Occup Med Toxicol. 2016;11(1):16.

36. Lette A, Ambelu A, Getahun T, Mekonen S. A survey of work-related injury among building construction workers in southwestern Ethiopia. Int J Ind Ergon. 2018:68:57-64.

37. Lette A, Kumbi M, Hussen A, Nuriye S. Determinants of occupational injury among building construction employees in southeastern Ethiopia. IJ Tropic Dis Health. 2018;34(4):1-11.

38. Dodo M. The application of health and safety plan in Nigerian construction firms. Jordan J Civil Eng. 2014;159(3175):1-7.

39. Tolera TB. Occupational hazards in construction industry: case studies from housing and construction workers at Addis Ababa, Ethiopia. Int J Res Granthaalayah. 2016;4(9):84-96.

40. Moradinazar M, Kurd N, Farhadi R, Amee V, Najafi F. Epidemiology of workrelated injury among construction workers of llam (Western Iran) during 2006-2009. Iran Red Crescent Med J. 2013;15(10):e8011.

41. Sashidharan C, Gopalakrishnan S. Prevalence and determinants of external injury among industrial workers in an urban area of Kancheepuram district, Tamil Nadu. Int J Commun Med Pub Health. 2017:4(12):4722-7.

42. Abbas RA, Zalat MM, Ghareeb NSE. Non-fatal occupational injury and safety climate: a cross-sectional study of construction building workers in Mit-Ghamr City, Dakahlia governorate, Egypt. Open J Safety Sci Tech. 2013;3(04):69.

43. Tadesse T, Kumie A. Prevalence and factors affecting work-related injury among workers engaged in small and medium-scale industries in Gondar wereda, north Gondor zone, Amhara regional state, Ethiopia. Ethiop J Health Dev. 2007;21(1):25-34

44. Kiconco A, Ruhinda N, Kyobutungi V, Watya S, Bazeyo W. Determinants of occupational injury among building construction Workers in Kampala City, Uganda. Annals Glob Health. 2017;83(1):86.

45. Zheng L, Xiang H, Song X, Wang Z. Nonfatal unintentional injury and related factors among male construction workers in Central China. Am J Ind Med. 2010;53(6):588-95.

46. Breslin FC, Smith P. Age-related differences in work injury: a multivariate, population-based study. Am J Ind Med. 2005;48(1):50-6.

47. Smith PM, Saunders R, Lifshen M, Black O, Lay M, Breslin FC, et al. The development of a conceptual model and self-reported measure of occupational health and safety vulnerability. Accid Anal Prev. 2015;82:234-43.

48. Rohlman DS, Parish M, Elliot DL, Montgomery D, Hanson G. Characterizing the needs of a young working population: making the case for total worker health in an emerging workforce. J Occup Environ Med. 2013;55:S69-72.

49. Kjestveit K, Tharaldsen J, Holte KA. Young and strong: what influences injury rates within building and construction? Saf Sci Monit. 2011;15(2):1-15.

50. Alizadeh SS, Mortazavi SB, Sepehri MM. Analysis of occupational accident fatalities and injury among male group in Iran between 2008 and 2012. Iran Red Crescent Med J. 2015;17(10):e18976.

51. Mohamadfam L. Evaluation of occupational accidents and their related factors in Iranian aluminum company in 1999; 2001.

52. Rahmani A, Khadem M, Madreseh E, Aghaei H-A, Raei M, Karchani M. Descriptive study of occupational accidents and their causes among electricity distribution company workers at an eight-year period in Iran. Saf Health Work. 2013:4(3):160-5.

53. Gizaw Z, Gebrehiwot M, Teka Z, Molla M. Assessment of occupational injury and associated factors among municipal solid waste management workers in Gondar town and Bahir Dar City, Northwest Ethiopia, 2012. J Med Medic Sci. 2014;5(9):181-92.

54. Jensen OC, Sørensen JF, Kaerlev L, Canals ML, Nikolic N, Saarni H. Selfreported injury among seafarers: questionnaire validity and results from an international study. Accid Anal Prev. 2004;36(3):405-13.

55. Yiha O, Kumie A. Assessment of occupational injury in tendaho agricultural development SC, afar regional state. Ethiopian J Health Dev. 2010;24(3):167174.

56. Simpson SA, Wadsworth EJ, Moss SC, Smith AP. Minor injury, cognitive failures and accidents at work: incidence and associated features. Occup Med. 2005:55(2):99-108.

57. Hansen CP. A causal model of the relationship among accidents, biodata, personality, and cognitive factors. J Appl Psychol. 1989;74(1):81.

58. Arthur W, Barret GV, Alexander RA. Prediction of vehicular accident involvement: a meta-analysis. Hum Perform. 1991:4(2):89-105.

59. Widia M, Dawal SZM. The effect of hand-held vibrating tools on muscle activity and grip strength. Aust J Basic Appl Sci. 2011;5(11):198-211.

60. Muema LM, Gatebe E, Kirui B, Adrian AA. Awareness of construction workers on occupational hazards, illness and injury associated with construction industry in Mombasa County. J Nurs Health Sci. 2015:4(6):75-82.

61. Tadesse S, Bezabih K, Destaw B, Assefa Y. Awareness of occupational hazards and associated factors among welders in Lideta Sub-City, Addis Ababa, Ethiopia. J Occup Med Toxicol. 2016;11:15.

62. Beyene Gebrezgiabher B, Tetemke D, Yetum T. Awareness of occupational hazards and utilization of safety measures among welders in Aksum and Adwa towns, Tigray region, Ethiopia. J Environ Public Health. Volume 2019, Article ID 4174085. https://doi.org/10.1155/2019/4174085.

63. Bhattacherjee A, Chau N, Sierra CO, Legras B, Benamghar L, Michaely J-P, et al. Relationships of job and some individual characteristics to occupational injury in employed people: a community-based study. J Occup Health. 2003:45(6):382-91.

64. Tanga A, Tessema F, Jilo G. Prevalence of occupational injury and associated factors among small-scale Industries Workers in Arba Minch Town, southern Ethiopia, 2016. Int J Pub Health Safe. 2018;3(152):2.

65. Ntili M, Emuze F, Monyane T, editors. The Impact of Substance Abuse in Construction: Examples from Bloemfontein, South Africa. In: Proceedings of the 6th International Conference on Engineering and Production Management; 2015.

66. Ghosh AK, Bhattacherjee A, Chau N. Relationships of working conditions and individual characteristics to occupational injury: a case-control study in coal miners. J Occup Health. 2004;46(6):470-80.

67. Wang L, Wheeler K, Bai L, Stallones L, Dong Y, Ge J, et al. Alcohol consumption and work-related injury among farmers in Heilongjiang Province, People's Republic of China. Am J Ind Med. 2010;53(8):825-35.

\section{Publisher's Note}

Springer Nature remains neutral with regard to jurisdictional claims in published maps and institutional affiliations.

Ready to submit your research? Choose BMC and benefit from:

- fast, convenient online submission

- thorough peer review by experienced researchers in your field

- rapid publication on acceptance

- support for research data, including large and complex data types

- gold Open Access which fosters wider collaboration and increased citations

- maximum visibility for your research: over $100 \mathrm{M}$ website views per year

At $\mathrm{BMC}$, research is always in progress.

Learn more biomedcentral.com/submissions 